\title{
The Determinants of Chief Financial Officer's Compensation in the Service Industry
}

\author{
Amarjit Gill ${ }^{*}, 1$, Nahum Biger ${ }^{1}$, Chenping Pai ${ }^{2}$, Harvinder S. Mand ${ }^{3}$ and Suraj Parkash Sharma ${ }^{4}$ \\ ${ }^{1}$ College of Business Administration, TUI University, CA, 90630, USA \\ ${ }^{2}$ School of Management, New York Institute of Technology, NY, USA \\ ${ }^{3}$ Sikh National College, Banga, Punjab, India \\ ${ }^{4}$ GTB National College, Dakha, Ludhiana, Punjab, India
}

\begin{abstract}
This study examines the relationship between i) the firm size and the Chief Financial Offer's (CFO) compensation and ii) the corporate performance and the CFO compensation in the service industry. Empirical results show that the CFO compensation is positively related to the firm size, net profit margin, and asset turnover. This paper offers useful insights for the service industry owners/operators based on empirical evidence.
\end{abstract}

\section{INTRODUCTION}

An agency problem has been seen to be prevalent in the service industry [1]. Because of the agency problem, the issues of executive compensation have been a subject of debate and research. The modern history of executive compensation research began in the early 1980s. The separation of ownership and control in modern corporations is the quintessential agency problem suggested by Berle and Means [2] and formalized by Jensen and Meckling [3].

An agency problem exists when management and shareholders have conflicting ideas on how the company should be run. For example, an agent might establish an agenda to run the company that is not necessarily in line with shareholders' interest. To minimize the agency problem, the owners (principal) try to control agent's incentives [4] that take the form of salary, bonus, long-term rewards (e.g., stock options) and fringe benefits [5]. Empirical evidence points out to the fact that executives tend to manipulate earnings through discretionary accruals in order to increase their bonus $[6,7]$. In some Canadian corporations (e.g., Livent Inc., Corel Corporation, and Nortel), the Ontario Securities Commission accused senior executives of "overseeing a massive fraud" [8]. In response to allegations about lack of accountability by the boards of directors in the mid 1990s, the Toronto Stock Exchange (TSX) adopted corporate governance guidelines for publically traded firms listed on the Toronto stock exchange [8].

The CFO being a part of corporate governance, plays an important role in managing the business in order to attain the objective of maximizing shareholders' wealth [9]. Although the CFOs are not the only persons responsible for the firm performance, they try to catalyze superior business performance by i) helping craft executable strategies, ii) embedding finance capabilities and expertise throughout the company, iii) fostering a disciplined and fact-based approach to

*Address correspondence to this author at the College of Business Administration, TUI University, CA, 90630, USA; E-mail: AGill@tuiu.edu decision making, and iv) providing a steady beacon for change and transformation in the organizations [10,11].

Since CFOs play an important role in maximizing shareholders' wealth, the purpose of this study is to examine the relationship between i) the corporate performance and the CFO compensation and ii) the firm size and the CFO compensation in the service industry.

Authors such as Early and Cleverley [12] and Langer [13] have done some research on the CFO compensation.

Most other empirical studies on executive compensation were conducted on industrial firms. In the service industry which is not involved in manufacturing, there might be other factors that affect CFO compensation because in this industry the total investment in machinery and equipment is almost non-existent. If this industry leases the facilities (buildings) then the total capital that is invested is mainly in working capital [14].

The selection of exploratory variables is based on the previous empirical work on agency theory. However, the choice of variables is sometimes limited because of lack of relevant data. As a result, the set of proxy variables includes two factors: corporate performance (net profit margin, return on equity, and asset turnover) and firm size (total assets). Insufficient data precluded the use of other variables such as $\mathrm{CFO}$ tenure at the firm, employee attributes (e.g., education and on the job training), etc.

Therefore we focused on examining and explaining the variation of CFO compensation in service industry firms. However, there has not been much research conducted on the CFO compensation in the service industry.

\section{FIRM SIZE, CORPORATE PERFORMANCE, AND} THE CFO COMPENSATION

\section{Firm Size}

One of the most important influences on executive compensation reported in the literature is the firm size measured by book value of assets [15]. Nourayi and Mintz [16] indi- 
cate that the firm size appears to be a significant explanatory variable for executive cash compensation. Early and Cleverley [12] and Langer [13] also describe that the firm size influences the CFO compensation. It is expected that firm size will have a positive impact on the CFO compensation.

\section{Corporate Performance}

The relationship between the corporate performance and the executive compensation has been empirically tested in several studies. Murphy [17, 18] and Kerr and Kren [19] found significant relationship between corporate performance and executive compensation. Lambert, Larcker, and Baker [20] found that executives who are awarded fixed salary lack a direct incentive to promote corporate performance because they do not share in the resulting gains in the firm's value. Nourayi and Mintz [16] reported that accountingbased measures of performance are positively correlated with executives' cash compensation.

Diamond and Verrechia [21] indicate that because managers serve as agent rather than owners of the firms, corporate incentives (e.g., bonus, stock options, and other recognition awards) can motivate them to make sound business decisions. In addition, firm's accounting performance is considered direct and immediate measure to induce management incentives that motivate executives to act in the favor of corporations [22]. Healy [23] indicates that firm's accounting performance affects the typical bonus contracts between a firm and its executives. Chalmers, Koh, and Stapledon [24] also found a positive relationship between the firm performance and executive bonus. Rose and Shepard [25] argue that the executive compensation is higher for diversified firms than undiversified firms.

Stock-based managerial incentives are believed to be powerful tools by which shareholders can minimize agency problem [26]. Stock based incentives plan (right to purchase company stock at a given price) is a one such long-term incentive plan for executives [27]. Abowd and Kaplan [27] found a strong link between the corporate performance and executives' stock compensation. Bebchuk [28] also indicates that equity based compensations increased considerably in the new-economy firms.

The results of research in executive compensation and actual performance have been mixed. For example, Murphy and Salter [29], Aupperle, Figler, and Lutz [30], and Madura, Martin, and Jessel [31] found that there was no statistically significant relationship between changes in return on equity and executive compensation. However, a study by Veliyath and Bishop [32] found that firms with high return on equity reward their executives with higher cash compensation.

In summary, literature review shows mixed results regarding the relationship between the corporate performance and executive compensation.

Prior research on the CFO compensation has yielded two primary conclusions. First, the improvement in accounting performance positively affects the current executive compensation [33]. Second, accounting performance often has a greater effect on the executive compensation than the stock price performance [34]. In addition, the decisions related to the CFO compensation (bonus and stock options) are made based on the firm's accounting performance. Therefore, it is theorized that the CFO compensation is the function of the firm size [total assets (TA)] and corporate performance [net profit margin (NPM), return on equity (ROE), and asset turnover (AT)] in the service industry.

Hence the following hypothesis is formulated:

H1: The CFO compensation is the function of the firm size and the corporate performance (NPM, ROE, and AT) in the service industry.

Conjecture: There might be differences regarding the nature of the relationship between firm size, firm performance, and the CFO compensation based on manufacturing and service industries.

\section{METHODOLOGY AND DATA}

\section{Measurement}

To remain consistent with previous studies, measures pertaining to the firm performance and the CFO compensation were adopted from both Choi's [35] and Zhou's [36] studies.

The change in firm performance from 2003 to 2004 and 2004 to 2005 was the independent variable in this study. The changes in firm performance were measured by using three ratios (proxy variables): i) NPM, ii) ROE, and iii) AT.

The change in firm size (independent variable) was measured by using the change in total assets (TA) of the firm (proxy variable) from 2003 to 2004 and 2004 to 2005.

The change in CFO compensation from 2004 to 2005 was the dependent variable in this study. The CFO compensation was measured as annual salary plus bonus. All of these categories of compensation were available on the proxy statements. This study excluded deferred compensation benefits like pensions, profit sharing plans, etc., because most of the companies were missing the information.

Logs and dlogs of the changes in the firm performance ratios, TA, and the CFO compensation were calculated before the regression analysis was performed to test the relationships between i) firm size and CFO compensation and ii) corporate performance and the CFO compensation.

One dummy variable, stock options, was used to determine whether companies offering stock options tend to pay less cash compensation. The stock option dummy variable was coded " 1 " for firms that provide stock options in addition to cash compensation and " 0 " for firms that do not provide stock options in addition to cash compensation.

\section{Sample and Procedures}

The study constructed a database from a selection of approximately 300 financial-report announced by public companies between January 1, 2003 and December 31, 2005. The selection was drawn from www.sedar.com, www.sec.gov/edgar.shtml, and www.hoovers.com to collect a sample of the service industry companies. Out of approximately 300 financial-reports announced by public companies between January 1, 2003 and December 31, 2005, only 160 financial reports were usable.

Most other empirical studies on executive compensation were conducted on industrial firms. Therefore, we chose service industry firms (hospitality services, telecommunica- 
tion services, transportation services, business services, financial services, and retail services) to find the determinants of the CFO compensation.

\section{Data Collection}

Numerical (quantitative) and financial data were collected to test the hypothesis. Financial statements and proxies submitted by the service companies to the Securities and Exchange Board of USA were used to collect data.

Based on the hypothesis, the CFO compensation can be modeled as follows:

$\mathrm{COMP}_{\mathrm{ji}}=\mathrm{b}_{0}+\mathrm{b}_{1} * \mathrm{NPM}+\mathrm{b}_{2} * \mathrm{ROE}+\mathrm{b}_{3} * \mathrm{AT}+\mathrm{b}_{4} * \mathrm{TA}+\mathrm{b}_{5}$ *DUMMY

where $b_{0}=$ constant of the regression equation

$b_{1}, b_{2}, b_{3}, b_{4}$ and $b_{5}=$ coefficient of NPM, ROE, AT, TA, and DUMMY

COMPji $=$ The $\mathrm{CFO}$ compensation for firm $\mathrm{j}$ received in 2004-2005

DUMMY $=$ Stock options dummy variable with $1=$ firms provided stock options in addition to cash compensation and $0=$ firms did not provide stock options in addition to cash compensation.

COMP $=$ The natural logarithm of the CFO cash compensation (salary plus bonus)

Net profit margin $(\mathrm{NPM})=$ Net profit after interest and tax $/$ sales

Return on equity $(\mathrm{ROE})=$ Net profit after interest and tax $/$ owners' equity

Asset turnover $(\mathrm{AT})=$ Sales / total assets

Total Assets $(\mathrm{TA})=$ Current assets + long-term assets

\section{Testing of Hypotheses}

Data were processed with the Statistical Package for the
Social Sciences (SPSS). We used multiple linear regression to accept or reject our null hypothesis and used $\mathrm{p}<.05$ as our level of significance.

\section{Relationship Between Firm Size, Corporate Perform- ance, and the CFO Compensation}

It was hypothesized that the CFO compensation is the function of the firm size and the corporate performance (NPM, ROE, and AT) in the service industry.

Positive relationships between i) TA (2005) and the CFO compensation, ii) NPM (2005) and the CFO compensation, iii) AT (2005) and the CFO compensation were found; that is, the CFO compensation is the function of current year's TA, current year's NPM, current year's AT in the service industry firms (see Table 1).

Non-significant relationships between i) TA (2004) and the CFO compensation, ii) NPM (2004) and the CFO compensation, iii) ROE (2004 and 2005) and the CFO compensation, iv) AT (2004) and the CFO compensation, and v) stock options (2004 and 2005) and the CFO compensation were found; that is, the CFO compensation is not the function of $i$ ) previous year's TA, ii) previous year's NPM, iii) current and previous year's ROE, iii) previous year's AT, and v) current and previous year's stock options in the service industry (see Table 1).

Test for multi-co linearity: All VIF coefficients except TA (2005) and AT (2005) are less than 2 and tolerance coefficients are greater than 0.5 except TA (2005) and AT (2005). Nevertheless we performed additional regression test that are reported in the end of the section before the discussion.

The regression equation is as follows:

CFO Compensation $(2005)=0.094+1.137 \mathrm{TA}(2004)+$ 9.070 TA $(2005)+0.880 \mathrm{NPM}(2004)+2.086 \mathrm{NPM}(2005)$ -0.092 ROE (2004) + 0.118 ROE (2005) + 0.016 AT (2004)

Table 1. Regression Coefficients $\mathbf{s}^{\mathrm{a}, \mathrm{b}}$

\begin{tabular}{|c|c|c|c|c|c|c|c|}
\hline & \multicolumn{2}{|c|}{ Unstandardized Coefficients } & \multirow{2}{*}{$\frac{\text { Standardized Coefficients }}{\text { Beta }}$} & \multirow{2}{*}{$\mathbf{t}$} & \multirow{2}{*}{ Sig. } & \multicolumn{2}{|c|}{ Collinearity Statistics } \\
\hline & B & Std. Error & & & & Tolerance & VIF \\
\hline (Constant) & 0.094 & 0.120 & & 0.788 & 0.432 & & \\
\hline TA (2004) & 1.137 & 1.015 & 0.090 & 1.119 & 0.265 & 0.897 & 1.114 \\
\hline TA (2005) & 9.070 & 2.515 & 0.742 & 3.606 & 0.000 & 0.137 & 7.308 \\
\hline NPM (2004) & 0.880 & 0.698 & 0.122 & 1.261 & 0.209 & 0.617 & 1.620 \\
\hline NPM (2005) & 2.086 & 0.634 & 0.339 & 3.289 & 0.001 & 0.547 & 1.829 \\
\hline ROE (2004) & -0.092 & 0.128 & -0.062 & -0.715 & 0.476 & 0.780 & 1.282 \\
\hline ROE (2005) & 0.118 & 0.084 & 0.127 & 1.409 & 0.161 & 0.716 & 1.397 \\
\hline AT (2004) & 0.016 & 0.064 & 0.020 & 0.244 & 0.808 & 0.896 & 1.116 \\
\hline AT (2005) & 1.149 & 0.348 & 0.676 & 3.298 & 0.001 & 0.138 & 7.247 \\
\hline Stock Options (2004) & -0.079 & 0.097 & -0.072 & -0.814 & 0.417 & 0.740 & 1.352 \\
\hline Stock Options (2005) & 0.085 & 0.102 & 0.072 & 0.830 & 0.408 & 0.765 & 1.307 \\
\hline
\end{tabular}

${ }^{a}$ Dependent Variable: CFO Compensation (2005).

${ }^{\mathrm{b}}$ Independent Variables: Total Assets (2004), Total Assets (2005), Net Profit Margin (2004), Net Profit Margin (2005), Return on Equity (2004), Return on Equity (2005), Asset Turnover (2004), Asset Turnover (2005), Stock Options (2004), and Stock Options (2005). Stock options were dealt with as a single dummy variable $1=$ firms provided stock options in addition to cash compensation and $0=$ firms did not provide stock options in addition to cash compensation. 
+ 1.149 AT (2005) - 0.079 Stock Options (2004) + 0.085 Stock Options (2005).

Table 2. Model Summary

\begin{tabular}{|c|c|c|c|c|c|}
\hline Model & R & $\begin{array}{c}\text { R } \\
\text { Square }\end{array}$ & $\begin{array}{c}\text { Adjusted R } \\
\text { Square }\end{array}$ & $\begin{array}{c}\text { Std. Error of } \\
\text { the Estimate }\end{array}$ & $\begin{array}{c}\text { Durbin- } \\
\text { Watson }\end{array}$ \\
\hline \hline 1 & $0.427^{\mathrm{a}}$ & 0.183 & 0.125 & 0.4482620371 & 2.025 \\
\hline
\end{tabular}

a Predictors: (Constant), Stock Options (2005), TA (2005), TA (2004), NPM (2004), ROE (2005), AT (2004), ROE (2004), Stock Options (2004), NPM (2005), AT (2005)

${ }^{\mathrm{b}}$ Dependent Variable: CFO Compensation (2005).

Note that around $18.3 \%\left(\mathrm{R}^{2}=0.183\right)$ of the variance in the degree of CFO compensation can be explained by the degree of Stock Options (2005), TA (2005), TA (2004), NPM (2004), ROE (2005), AT (2004), ROE (2004), Stock Options (2004), NPM (2005), AT (2005) (see Table 2).

Table 3. ANOVA ${ }^{\text {b }}$

\begin{tabular}{|c|c|c|c|c|c|c|}
\hline Model & & $\begin{array}{c}\text { Sum of } \\
\text { Squares }\end{array}$ & df & $\begin{array}{c}\text { Mean } \\
\text { Square }\end{array}$ & F & Sig. \\
\hline \hline 1 & Regression & 6.331 & 10 & 0.633 & 3.151 & $0.001^{\mathrm{a}}$ \\
\hline & Residual & 28.332 & 141 & 0.201 & & \\
\hline & Total & 34.664 & 151 & & & \\
\hline
\end{tabular}

${ }^{a}$ Predictors: (Constant), Stock Options (2005), TA (2005), TA (2004), NPM (2004), ROE (2005), AT (2004), ROE (2004), Stock Options (2004), NPM (2005), AT (2005).

${ }^{\mathrm{b}}$ Dependent Variable: CFO Compensation (2005).

As shown in Table 3, ANOVA's test is also significant at 0.001 . Further examination of the data indicates that some of the 'explanatory' variables exhibit relatively high correlations. Therefore we performed an additional regressions test where only explanatory variables that have non-significant linear correlations among them were included. The variable that are included are: NPM (2005), AT (2005) and TA (2005) with the following results:

\begin{tabular}{|c|c|c|c|}
\hline $\mathbf{R}$ & R-Square & Adj. R-Square & S.E.E. \\
\hline 0.323 & 0.104 & 0.087 & 0.454 \\
\hline
\end{tabular}

Predictors: constant, TA (2005), NPM (2005), TA (2005).

And the regression results were:

\begin{tabular}{|c|c|c|c|c|}
\hline & B & SE & T & P \\
\hline Constant & 0.105 & 0.040 & 2.641 & 0.009 \\
\hline NPM (2005) & 1.302 & 0.376 & 3.466 & 0.001 \\
\hline AT (2005) & 0.947 & 0.338 & 2.801 & 0.006 \\
\hline TA (2005) & 7.379 & 2.429 & 3.038 & 0.003 \\
\hline
\end{tabular}

Dependent Variable: CFO Compensation (2005).

\section{DISCUSSION}

The main purpose of this study was to examine whether the remuneration paid to the CFOs of the service industry firms is related to the firm size and the corporate performance. Empirical results show that the CFO compensation is positively related to the firm size, net profit margin, and asset turnover.

These results support the findings of Early and Cleverley [12] and Langer [13] in which they indicate that the CFO compensation is impacted by the firm size and the corporate financial performance. In addition, the results of this paper support the findings of Boschen, Duru, Gorden, and Smith [33] in which they indicate that the improvement in accounting performance positively affects the current executive compensation.

\section{Limitations}

This study is limited to the service industry firms only. Because this study was co-relational and non-experimental, a causal link between firm performance and the CFO compensation cannot be definitively established. Therefore, a link between the firm performance and the CFO compensation can only be suggested. Additionally, the findings of this study could only be generalized to service firms similar to those that participated in this research.

\section{Future Research}

To further enhance the generalization of the findings beyond the service industry, additional research in other fields is advocated, complemented by studies focusing on a longitudinal design, allowing for tracking and assessing the evolution of the determinants of the CFO compensation over time. The definition of the CFO compensation used in this study can be extended by including other important items such as value of stocks granted, capital gains/losses on holding of stocks and options during the year, and pension benefits.

\section{REFERENCES}

[1] Qian YJ. Managers' stock ownership and performance in lodging industry. University of Nevada: Las Vegas 1996.

[2] Berle AA, Means GC. The modern corporation and private property. New York 1932.

[3] Jensen M, Meckling W. Theory of the firm: managerial behavior, agency costs and ownership structure. J Financ Econ 1976; 3: 30560 .

[4] Stroh LK, Brett JM, Baumann JP, Reilly AH. Agency theory and variable pay compensation strategies. AMJ 1996; 39: 751-67.

[5] Williams K. CFO compensation is up; So is perception of financial officers. Manage Account 1993; 75: 16.

[6] Gaver JJ, Gaver KM, Austin, JR. Additional evidence on bonus plans and income management. J Account Econ 1995; 19: 3-28.

[7] Holthausen RW, Larcker DF, Sloan RG. Annual bonus schemes and the manipulation of earnings. J Account Econ 1995; 19: 29-74.

[8] Bujaki M, McConomy BJ. Corporate governance: factors influencing voluntary disclosure by publicly traded canadian firms. Can Account Perspect 2002; 1: 105-39.

[9] Lee J. Corporate governance - and why you need it. Asiamoney 2001; 12: 24-7.

[10] Silver S. Finance as a business catalyst. Corp Financ Rev 2006; 11 : 26-31.

[11] Nayak M. India's best CFO; He's Ratan Tata's financial navigator at Tata motors, structuring complex acquisitions, raising capital as attractive rates, wielding the axe on costs and showing the road ahead in the automotive major's quest to become a global auto brand. Bus Today 2006: 66.

[12] Early LA, Cleverley WO. CFO compensation increasingly linked to performance. Healthcare Financ Manage 1995; 49: 44-9.

[13] Langer S. Factors affecting CFO compensation. Strategic Financ 2000; 81: 38-44.

[14] Gill A, Biger N, Bhutani S. Corporate performance and the chief executive officer's compensation in the service industry. Open Bus J 2008; 1: 53-7. 
[15] Crumley C. A study of the relationship between firm performance and CEO compensation in the US. commercial banking industry. $\mathrm{J}$ Appl Manage Entrepreneurship 2008; 13: 26-46.

[16] Nourayi MM, Mintz SM. Tenure, firm's performance, and CEO's compensation. Managerial Financ 2008; 34: 524-36.

[17] Murphy KJ. Corporate performance and managerial remuneration: An empirical analysis. J Account Econ 1985; 7: 11-42.

[18] Murphy KJ. Executive compensation. Handbook Labor Econ 1998; 3.

[19] Kerr JL, Kren L. Effects of relative decision monitoring on chief executive compensation. AMJ 1992; 35: 370-97.

[20] Lamburt R, Larcker D, Baker GP. An analysis of the use of accounting and market measures of performance in executive compensation contracts. J Account Res 1987; 25: 85-129.

[21] Diamond DW, Verrechia RE. Optimal managerial contracts and equilibrium security prices. J Finance 1982; 37: 275-87.

[22] Baker GP, Jensen MC, Murphy KJ. Compensation and incentives: Practices Vs. theory. J Financ 1988; 43: 593-616.

[23] Healy PM. The effect of bonus schemes on accounting decisions. J Account Econ 1985; 7: 85-107.

[24] Chalmers K, Koh PS, Stapledon G. The determinants of CEO compensation: Rent extraction or labour demand? Br Account Rev 2006; 38: 259-60

[25] Rose NL, Shepard A. Firm diversification and CEO compensation: Managerial ability or executive entrenchment? RAND J Econ 1997; 28: 489-514.
[26] Giancarlo S. Stock-Related compensation and product-market competition. RAND J Econ 2000; 31: 22-42.

[27] Abowd JM, Kaplan DS. Executive compensation: Six questions that need answering. J Econ Perspect 1999; 13: 145-68.

[28] Bebchuk L. The growth of executive pay. Oxford Rev Econ Policy 2005; 21: 283-01.

[29] Murphy K, Salter MS. Should CEO pay be linked to results? Harvard Bus Rev 1975; 53: 66-73.

[30] Aupperle KE, Figler RA, Lutz RC. Do the in search of excellence firms effectively match CEO compensation to corporate performance? J Managerial Issues 1991; 111: 445-57.

[31] Madura J, Martin AD, Jesse KA. Determinants of CEO compensation in small publicly-traded businesses. Am Bus Rev 1996; 14: 808.

[32] Veliyath R, Bishop JW. Relationship between CEO compensation and firm performance: Empirical evidence of labor market norms. Int J Organ Anal 1995; 3: 268-83.

[33] Boschen JF, Duru A, Gorden, LA, Smith KJ. Accounting and stock price performance in dynamic CEO compensation arrangements. Account Rev 2003; 78: 143-68.

[34] Antle R, Smith A. Measuring executive compensation: methods and an application. J Account Res 1985; 23: 296-325.

[35] Choi Y. Determinants of CEO compensation in the hospitality industry. ProQuest information and learning company: USA 2002.

[36] Zhou X. CEO pay, firm size, and corporate performance. Can J Econ 2000; 33: 213-51.

(c) Gill et al.; Licensee Bentham Open.

This is an open access article licensed under the terms of the Creative Commons Attribution Non-Commercial License (http://creativecommons.org/licenses/by$\mathrm{nc} / 3.0 /$ ) which permits unrestricted, non-commercial use, distribution and reproduction in any medium, provided the work is properly cited. 